yeast and give no electrical response. ${ }^{6,7}$ On the contrary, the unrefined sugars, such as Barbadoes, give a vigorous fermentation and corresponding electrical response. It is not therefore surprising that $\mathrm{Mr}$. Wolfenden's experiments conducted with pure sucrose gave negative results, and the discrepancy between us may thus be explained.

In the two sets of experimental conditions Mr. Wolfenden used pure sucrose while I used unrefined sugar, and I cannot agree that "it seems unlikely that the impurities could play a decisive part", as they evidently promote yeast-sugar fermentation and thus constitute a decisive factor in the electrical response.

Corley Croft,

New Milton, Hants, July 11 .

1 Wolfenden, J. H., NATURE, 128, 69, July 11, 1931.

2 Proc. Roy. Soc., B, 84; 1911.

3 Elema, B., "De bepaling van de Oxydatie-Reductiepotentiaal in Bacteriencultures en hare beteekenis voor de Stofwisseling ". Delft, 1932.

4 Gillespie, L. J., " Reduction Potentials of Bacterial Cultures and of Water-Logged Soils", Soil Science, 9; 1920.

${ }^{5}$ Hewitt, L. F., "Oxidation-Reduction Potentials in Bacteriology and Biochemistry"." Publication of the London County Council, 1930.

Down 554, April 11, 1931.

? Potter, M. C., "A Method of Measuring the Electricity produced during the Decomposition of Organic Compounds ", Zentralb. Bakteriologie, Abtl. 2, Bd. 84; 1931 .

\section{Hydrolysis in Green Plants by Moonlight}

In view of the recent interesting discussion on ' Lunar Periodicity in Organisms', which has appeared in these columns, ${ }^{1}$ some very simple experiments, carried out in South Africa in the grounds of Huguenot University College, would appear to throw some light on the subject.

On a bright moonlight evening, about 10.30 P.M., on the 9 th day of the moon, that is, near the time of maximum polarisation, I noticed a very sharp shadow cast by a vine leaf on the one beneath it, the tip being very brightly illuminated. The lower leaf was picked

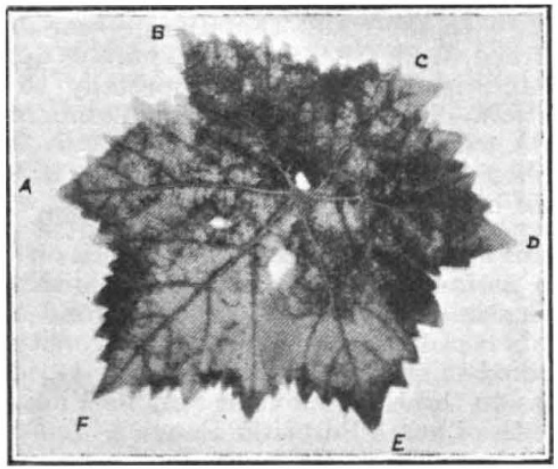

FIG. 1.-Hydrolysis of starch by exposure to moonlight of lobes $F, E$ of a vine-leaf.

and quickly plunged into 95 per cent alcohol. On staining with iodine, a remarkable disappearance of starch was found to have occurred in the portion irradiated by the moonlight (Fig. 1, $E$ and $F$ ), while the basal portion $A B C D$ in shadow still retained its starch.

Similar results had previously been found on exposing leaves of spinach and Tropceolum to moonlight, a portion of the leaf having been covered by cardboard or tinfoil. The exposed part of the leaf showed distinct hydrolysis, while the starch remained in the covered part.
This did not occur at full moon, as the light is not then polarised. It will be noted that these results are in accordance with those described in a former letter, ${ }^{2}$ and also with the effect produced by polarised skylight. ${ }^{3}$

Elizabeth Sidney Semmens.

University of London Club,

late Huguenot University College,

University of South Africa.

1 See NATURE, 130, 23, July 2, 1932.

3 Bot. Gaz., 90, 412, Dec. 30, 1930.

\section{Filtration of Plant Viruses}

FolxowING upon the publication of the interesting letter from Mr. MacClement and Dr. Henderson Smith upon the above subject, 1 it may be worth while recording the results of some similar work in this direction. During the past nine months, I have been filtering two potato mosaic viruses, $X$ and $Y,{ }^{2}$ by means of the same collodion membrane technique developed by W. J. Elford. This work has been carried out at the Molteno Institute at Cambridge under the direction of Prof. D. Keilin, to whom I am deeply indebted, I wish also to express my thanks to Dr. W. J. Elford for much assistance willingly given.

Before attempting to filter these two potato viruses through the collodion membranes, some preliminary filtration work was carried out with Pasteur-Chamberland candles. These experiments showed that while the $X$ virus was filterable through an $L_{3}$ and occasionally an $L_{5}$ candle, the virus $Y$ would not pass an $L_{1}$ candle. The experiments on filtration through the collodion membranes, while admittedly preliminary, showed that both viruses would pass a membrane of approximate pore size $0 \cdot 35 \mu$, and that both are held back by membranes of $0 \cdot 15 \mu$. This is a parallel case to that quoted by Messrs. MacClement and Henderson Smith, where Dr. Hamilton's virus would not pass an $L_{3}$ candle but would pass a membrane of $0 \cdot 30 \mu$ pore size.

The inability of the $Y$ virus to pass the $L_{1}$ candle is obviously not directly connected with the porosity of the candle or the size of the virus particle, but in all probability it is due to adsorption of the virus by the candle. I have found that if the virus complex, $X+Y$, is merely passed through a kieselguhr bed in a Buchner funnel, the filtrate invariably contains a 'pure culture' of the $X$ virus, the $Y$ being completely adsorbed to the kieselguhr; this offers a ready means of separating out a complex of these two viruses.

\section{Molteno Institute and}

Potato Virus Research Institute, School of Agriculture, Cambridge, July 25.

1 NATURE, 130, 129, July 23, 1932.

2 Proc. Roy. Soc., B, 109, 251-267; 1931.

\section{Production of Microscopic Test-Rulings}

In NATURE of Sept. 19, 1931, under "Birthdays and Research Centres ", I claimed that microscopic test-rulings up to 250,000 lines per inch had been produced in my laboratory.

Lately, for various reasons, I found it necessary to make a personal investigation into this claim, and I regret that I have been unable to find any evidence that rulings beyond 120,000 lines per inch have been produced here.

Lisbuoy, Irving Road,

Toorak, Melbourne, June 15. 